\title{
CHANGE IN BLOOD PRESSURE LEVELS IN COLLEGE STUDENTS
}

\author{
Luana Savana Nascimento de Sousaㄹ, Layla Gonçalves do Nascimento Macêdo², Jayne Ramos Araujo Moura², \\ Mayla Rosa Guimarães ${ }^{4}$, Regina Célia Vilanova Campelo ${ }^{5}$, Ana Roberta Vilarouca da Silva ${ }^{6}$
}

\footnotetext{
${ }^{1}$ Undergraduate Nursing student, Universidade Federal do Piauí (UFPI). Picos, Piauí, Brazil. E-mail: luanasavana@htmail.com

${ }^{2}$ Nurse, Family Health Strategy, Itainópolis. Itainópolis, Piauí, Brazil. E-mail: layla.enfermagem@hotmail.com

${ }^{3}$ Undergraduate Nursing student, UFPI. Picos, Piauí, Brazil. E-mail: jayne_moura@hotmail.com

${ }^{4}$ Undergraduate Nursing student, UFPI. Picos, Piauí, Brazil. E-mail: m_aylaguimaraes@hotmail.com

${ }^{5}$ M.Sc. in Sciences and Health. Technical Director of Federação de Ginástica do Piauí. Picos, Piauí, Brazil. E-mail: rcvcampelo@ hotmail.com

${ }^{6}$ Ph.D. in Nursing. Faculty, Nursing Program and Master's Program in Sciences and Health. UFPI. Picos, Piauí, Brazil. E-mail: robertavilarouca@yahoo.com.br
}

\begin{abstract}
The aim in this study was to evaluate the pressure levels in college students and their relation with socioeconomic level, lifestyle and biochemical data. This is a descriptive, cross-sectional study, conducted with 550 students from a public university in PicosPI, in 2013. A form containing socioeconomic data, lifestyle, waist circumference, blood pressure, fasting serum glucose, triglycerides and HDL-cholesterol was applied. We observed elevated blood pressure levels in $21.5 \%$ of males and $2.2 \%$ of females, with significant representation $(p<0.0001)$. There was a statistically significant association for smoking $(p<0.0001)$ and alcohol consumption $(p<0.0001)$ with systolic and diastolic blood pressure, as well as for waist circumference $(p=0.0039)$. When considering the quality of life for the coming years, it is important to note the need to implement measures that promote changes in lifestyle with the acquisition of healthy habits.

DESCRIPTORS: Students. Risk factors. Arterial pressure.
\end{abstract}

\section{ALTERAÇÃO DOS NÍVEIS DE PRESSÃO ARTERIAL EM UNIVERSITÁRIOS}

RESUMO: Objetivou-se avaliar os níveis pressóricos em universitários e sua relação com o nível socioeconômico, o estilo de vida e os dados bioquímicos. Trata-se de um estudo descritivo, transversal, desenvolvido com 550 estudantes de uma universidade pública de Picos-PI, em 2013. Foi aplicado um formulário contendo dados socioeconômicos, estilo de vida, medida da circunferência abdominal, pressão arterial, níveis séricos de glicemia de jejum, triglicerídeos e HDL-colesterol. Observaram-se níveis pressóricos elevados em $21,5 \%$ do sexo masculino e $2,2 \%$ nas mulheres, com representação significante $(p<0,0001)$. Houve associação estatisticamente significante para o tabagismo $(\mathrm{p}<0,0001)$ e para o consumo de álcool $(\mathrm{p}<0,0001)$ com a pressão arterial sistólica e diastólica, bem como para a circunferência abdominal $(\mathrm{p}=0,0039)$. Assim, pensando na qualidade de vida dos próximos anos, é importante observar a necessidade de implementação de medidas que promovam mudanças no estilo de vida com aquisição de hábitos saudáveis.

DESCRITORES: Estudantes. Fatores de risco. Pressão arterial.

\section{CAMBIOS EN LOS NIVELES DE LA PRESIÓN ARTERIAL DE UNIVERSITARIOS}

RESUMEN: El objetivo fue evaluar los niveles de presión arterial en estudiantes y su relación con el nivel socioeconómico, estilo de vida y datos bioquímicos. Estudio descriptivo, transversal, desarrollado con 550 estudiantes de una universidad pública de Picos-PI, Brasil, en 2013. Se aplicó formulario con informaciones socioeconómicas, estilo de vida, medición de la circunferencia de la cintura, presión arterial, niveles de glucosa en suero en ayunas, triglicéridos y HDL-colesterol. Fueron observados altos niveles de presión arterial en $21,5 \%$ de los hombres y $2,2 \%$ de las mujeres, con representación significativa $(p<0,0001)$. Hubo asociación estadísticamente significativa con tabaquismo $(\mathrm{p}<0,0001)$ y consumo de alcohol $(\mathrm{p}<0,0001)$, con presión arterial sistólica y diastólica, y también como para circunferencia de la cintura $(\mathrm{p}=0,0039)$. Así, para la calidad de vida en los próximos años, es preciso implementar medidas para promover cambios en el estilo de vida con adquisición de hábitos saludables.

DESCRIPTORES: Estudiantes. Factores de riesgo. Presión arterial. 


\section{INTRODUCTION}

Despite constant stimuli to adopt healthy life practices and the growing therapeutic arsenal, cardiovascular diseases are still the main cause of morbidity and mortality in developed and emerging countries. ${ }^{1}$ Data from the Ministry of Health appoint that, today, chronic conditions are responsible for $72 \%$ of the causes of death in Brazil. ${ }^{2}$ Arterial hypertension (AH) is one of the main risk factors for the worsening of this scenario, estimating that $25.5 \%$ of women and $20.7 \%$ of men aged $\geq 18$ years have blood pressure (BP) levels superior to normal parameters. ${ }^{3}$

Due to the high morbidity and mortality and negative repercussions for the quality of life, and due to their socioeconomic impact, the chronic conditions are a source of concern and lead to the identification of the need to implement public policies to raise the population's awareness about the main cardiovascular risk factors, as these conditions represent health problems that require continuous management by the patients over a long period. ${ }^{4}$

These factors can be verified in different populations, including college students. Upon getting into college, students go through different lifestyle changes that can favor the emergence of one or several risk factors for $\mathrm{AH}$ and other chronic conditions, such as increasingly insufficient physical exercise, consumption of substances like tobacco and alcoholic beverages and bad eating habits. ${ }^{5-6}$

It is important to highlight that, among college students, a high prevalence of cardiovascular risk factors is observed, which is a source of concern, as this group has access to information and is expected to serve as a model for the establishment of healthy life habits for the general population..$^{7-8}$ The objective in this study was to assess the pressure levels in college students and their relation with the socioeconomic level, lifestyle and biochemical data.

\section{METHOD}

A descriptive and cross-sectional study was developed with college students from a public university in a city in the interior of Piauí, Brazil.

The study population consisted of 2,868 male and female college students enrolled at the place of study. For the sample size, a formula was used for finite populations, resulting in 550 participants. A stratified sampling process was applied per course and graduation period by response to the invitation. The data were collected between January and March 2013.

The selection of the participants complied with the following inclusion criteria: being actively enrolled in one of the university's nine courses, age 18 years or older, and participating in all phases of the research.

Students present in the classroom were invited. On that occasion, the research objectives were explained, as well as what each student should do in participating, such as filling out a form with socioeconomic data, lifestyle including bad habits like smoking, drinking, and healthy habits like physical exercise. The waist circumference (WC) and BP were measured and blood was collected to assess the serum levels of venous glucose, triglycerides and HDL-cholesterol (with 12 hours of fasting). A laboratory was hired for the collection and biochemical analyses. The entire data collection took place at the university in a room booked in advance.

As to the lifestyle, students who did not practice at least 30 minutes per day of light or moderate activity five days per week were classified as sedentary; or 20 minutes per day of intense activity three or more days per week. Light or moderate activities are considered as: walking, walking on treadmill, bodybuilding, water gymnastics, gymnastics in general, swimming, martial arts, cycling and volleyball. Intense activities are: running, running on treadmill, aerobics, soccer, basketball and tennis. ${ }^{9}$

What smoking is concerned, the students were classified in four categories: daily smoking, occasional smokers, former smokers and non-smokers. Daily smokers were considered to be people who smoked at least one cigarette per day, one month before completing the questionnaire; occasional smokers were people who did not smoke daily; former smokers were people who, after having smoked, quit smoking at least one month earlier; and non-smokers were people who had never smoked or had been smoking for less than one month. ${ }^{10}$

As for drinking, the Alcohol Use Disorders Identification Test (AUDIT) was used as a measure, which is a ten-question test developed by the World Health Organization as a screening tool, specifically to identify people with harmful alcohol consumption, as well as people who have already developed an addiction. The version adapted for Brazil was used. ${ }^{11-12}$

The variables: waist circumference, triglycerides, HDL-cholesterol and fasting glucose were 
analyzed according to the recommendations of the Brazilian Society of Cardiology, ${ }^{13}$ and the pressure levels according to the VI Brazilian Hypertension Guidelines. $^{14}$

The data were analyzed through the Statistical Package for the Social Sciences (SPSS), version 20.0. For the descriptive analysis, absolute and relative frequencies were calculated, as well as central trend and dispersion measures. The Kolmogorov-Smirnov test was applied to assess the normality of the sample. Pearson's Chi-square and the Fisher-Freeman-Halton test were applied to check for discrepancies between the observed and expected frequencies of the events studied. The rejection level established for the null hypothesis was lower than or equal to 0.05 (5\%).

The development of the study followed the Brazilian and international ethical standards for research involving human beings and received approval from the Institutional Review Board of the Universidade Federal do Piaui, under protocol $\mathrm{n}$. 0408.0.045.000-11. Project funded by the call of the Infrastructure Program for Young Researchers of the Piauí Research Foundation.

\section{RESULTS}

The research involved 550 college students from the Bachelor programs in Nursing, Nutrition, Administration, Information Systems and Teaching Diploma programs in Mathematics, Pedagogics, Languages, History and Biology.

As regards the sample characteristics, what the socioeconomic data are concerned, $66.2 \%$ were female, $85.1 \%$ were between 18 and 25 years of age, with an average age of 22.6 years. The most predominant self-referred color was mulatto, corresponding to $51.6 \%$. As to the employment situation, $69.3 \%$ only studied. What the economic class is concerned, $51.8 \%$ were classified between classes $\mathrm{C} 1$ and $\mathrm{C} 2$, with a mean income of $\mathrm{R} \$ 1,629.00$. The large majority of the students $(86.7 \%)$ were single, and $39.6 \%$ lived with their parents.

What the practice of physical exercise is concerned, it is highlighted that $71.7 \%$ were sedentary. As for smoking, 91.8\% affirmed that they never smoked or were smoking for less than one month. And, regarding the drinking variable, $48.5 \%$ were classified in zone II, of medium risk.

The anthropometric data, pressure levels and biochemical data for the sample have been described in Table 1.
Table 1 - Anthropometric data, pressure levels and biochemical data among students from a public university. Picos-PI, 2013

\begin{tabular}{lrrc}
\hline Variables & \multicolumn{1}{c}{$\mathbf{n}$} & \multicolumn{1}{c}{$\%$} & Mean $\mathbf{\pm} \mathbf{S D}^{*}$ \\
\hline Waist circumference & & & $78.3 \pm 10.3$ \\
$\quad$ Normal & 518 & 94.2 & \\
$\quad$ High & 32 & 5.8 & \\
Fasting glucose & & & $83.3 \pm 11.9$ \\
$\quad$ Normal & 543 & 98.7 & \\
$\quad$ High & 7 & 1.3 & \\
Triglycerides & & & $122.2 \pm 55.0$ \\
$\quad$ Normal & 446 & 81.1 & \\
$\quad$ High & 104 & 18.9 & \\
HDL cholesterol & & & $43.9 \pm 8.0$ \\
$\quad$ Normal & 195 & 35.5 & \\
$\quad$ Low & 355 & 64.5 & \\
Blood pressure & & & SBP:: $109.9 \pm 12.1$ \\
$\quad$ Excellent & 369 & 67.1 & DBP\$: $69.9 \pm 9.7$ \\
$\quad$ Normal & 133 & 24.2 & \\
$\quad$ Borderline & 48 & 8.7 & \\
\hline
\end{tabular}

*Standard Deviation; †High Density Lipoprotein; ¥SBP - Systolic Blood Pressure; §DBP - Diastolic Blood Pressure.

Concerning the variable WC, $94.2 \%$ complied with normal parameters, and 5.8\% were classified as high (mean $78.3 \mathrm{~cm}$ ). $98.7 \%$ had their fasting glucose within normal parameters and only $1.3 \%$ for high glucose (mean $83.3 \mathrm{mg} / \mathrm{dl}$ ). What the triglyceride level is concerned, $18.9 \%$ of the sample showed higher than ideal parameters (mean $122.2 \mathrm{mg} / \mathrm{dl}$ ); Regarding HDL-cholesterol levels, $64.5 \%$ presented low levels (mean $43.9 \mathrm{mg} /$ $\mathrm{dl}$ ), and $8.7 \%$ revealed borderline BP levels (mean SBP $109.9 \mathrm{mmHg}$ and DBP $69.9 \mathrm{mmHg}$ ).

Table 2 displays the stratification of BP per sex, age range and economic class.

Table 2 - Stratification of blood pressure variable per sex, age range and economic class of students at a public university. Picos-PI, 2013

\begin{tabular}{|c|c|c|c|c|c|}
\hline \multirow{3}{*}{ Variables } & \multicolumn{4}{|c|}{ Blood pressure } & \multirow{3}{*}{$\mathbf{p}$} \\
\hline & \multicolumn{2}{|c|}{ Normal } & \multicolumn{2}{|c|}{ High } & \\
\hline & $\mathbf{n}$ & $\%$ & $\mathbf{n}$ & $\%$ & \\
\hline Sex & & & & & $<0.0001^{*}$ \\
\hline Female & 356 & 97.8 & 8 & 2.2 & \\
\hline Male & 146 & 78.5 & 40 & 21.5 & \\
\hline Age range & & & & & $<0.0001^{*}$ \\
\hline $18-25$ & 430 & 91.8 & 38 & 8.2 & \\
\hline $26-51$ & 72 & 87.8 & 10 & 12.2 & \\
\hline Economic class & & & & & SBP: $0.003^{*}$ \\
\hline A-B & 171 & 86.8 & 26 & 13.2 & DBP: $1.000^{*}$ \\
\hline C-D-E & 331 & 93.8 & 22 & 6.2 & \\
\hline
\end{tabular}


Sousa LSN, Macêdo LGN, Moura JRA, Guimarães MR, Campelo RCV, Silva ARV

When associating the socioeconomic variables with the BP, $21.5 \%$ of the male students showed high BP. The predominant age range was between 26 and 51 years old, with $12.2 \%$ presenting high BP levels. Significant representations were found for sex $(\mathrm{p}<0.0001)$ and age range $(\mathrm{p}<0.0001)$ in relation to SBP and DBP, and an association between economic class $(\mathrm{p}=0.003)$ and SBP.

Table 3 demonstrates the association between lifestyle (drinking, smoking and exercising) and BP.

Table 3 - Association between lifestyle (drinking, smoking and physical exercise) and blood pressure of students at a public university. PicosPI, 2013

\begin{tabular}{|c|c|c|c|c|c|}
\hline \multirow{3}{*}{ Variables } & \multicolumn{4}{|c|}{ Blood pressure } & \multirow{3}{*}{$\mathrm{p}$} \\
\hline & \multicolumn{2}{|c|}{ Normal } & \multicolumn{2}{|c|}{ High } & \\
\hline & $\mathbf{n}$ & $\%$ & $\mathbf{n}$ & $\%$ & \\
\hline Physical exercise & & & & & $>0,532^{*}$ \\
\hline Active & 136 & 87,7 & 19 & 12,3 & \\
\hline Sedentary & 376 & 95,2 & 19 & 4,8 & \\
\hline Smoking & & & & & $<0,0001^{*}$ \\
\hline $\begin{array}{l}\text { Daily or occasional } \\
\text { smokers }\end{array}$ & 39 & 86,7 & 6 & 13,3 & \\
\hline $\begin{array}{l}\text { Never smoked or } \\
\text { smoking for less } \\
\text { than one month }\end{array}$ & 463 & 91,7 & 42 & 8,3 & \\
\hline Drinking & & & & & $<0,0001^{*}$ \\
\hline Zone I - Zone II & 425 & 91,5 & 39 & 8,5 & \\
\hline Zone III - Zone IV & 77 & 89,5 & 9 & 10,5 & \\
\hline
\end{tabular}

It was verified that $4.8 \%$ of the sedentary individuals had increased BP. As regards smoking, $13.3 \%$ were considered daily or occasional smokers, with high pressure levels. Concerning alcohol use among the students, between zones II and IV, 10.5\% of students with high BP levels were found. A statistically significant association was found for smoking $(\mathrm{p}<0.0001)$ and drinking $(\mathrm{p}<0.0001)$ with SBP and DBP.

Table 4 displays the association between BP data and other components of the Metabolic Syndrome (MS) according to the National Cholesterol Education Program Adult Treatment Panel III (NCEP-ATP III).
Table 4 - Association between blood pressure and anthropometric and biochemical data of students at a public university. Picos-PI, 2013

\begin{tabular}{|c|c|c|c|c|c|}
\hline \multirow{3}{*}{ Variables } & \multicolumn{4}{|c|}{ Blood pressure } & \multirow{3}{*}{ p } \\
\hline & \multicolumn{2}{|c|}{ Normal } & \multicolumn{2}{|c|}{ High } & \\
\hline & $\mathbf{n}$ & $\%$ & $\mathbf{n}$ & $\%$ & \\
\hline Waist circumference & & & & & $0.0039^{*}$ \\
\hline Normal & 478 & 92.3 & 40 & 7.7 & \\
\hline High & 24 & 75.0 & 8 & 25.0 & \\
\hline Fasting glucose & & & & & $0.4742^{*}$ \\
\hline Normal & 496 & 91.4 & 47 & 8.6 & \\
\hline High & 6 & 85.7 & 1 & 14.3 & \\
\hline Triglycerides & & & & & $0.0575^{\dagger}$ \\
\hline Normal & 412 & 92.3 & 34 & 7.7 & \\
\hline High & 90 & 86.6 & 14 & 13.4 & \\
\hline HDL ${ }^{\ddagger}$ Cholesterol & & & & & $1.000^{\dagger}$ \\
\hline Normal & 169 & 86.7 & 26 & 13.3 & \\
\hline Low & 333 & 93.8 & 22 & 6.2 & \\
\hline
\end{tabular}

When associating BP with waist circumference, glucose, triglycerides, HDL-cholesterol, it was observed that $25.0 \%$ of the students had high waist circumference and pressure levels; $14.3 \%$ of the high glucose levels belonged to students with high BP levels; $13.4 \%$ of the college students stood out with high triglycerides and BP; $6.2 \%$ of the sample presented low plasma levels of HDL-cholesterol and above-normal BP. Statistical significance was found for waist circumference only $(\mathrm{p}=0.0039)$.

\section{DISCUSSION}

It was verified that most research participants were female. Concerning this variable, this finding may be related to the fact that women represent a majority in society ${ }^{15}$ and are also the most frequent sex in research samples involving college students. ${ }^{16-18}$ As for age, the most prevalent age range was between 18 and 25 years, the expected range for studies in this population, with results similar to other studies. ${ }^{18}$

In the association of the independent variables (sex, age range and economic class) to $\mathrm{BP}$, it was observed that the male population prevailed 
in the age range between 26 and 51 years. In the interpretation of the data, it was verified that the prevalence of high pressure levels in men in this age range who belonged to the groups with high purchasing power can be determined by the academic life behavior, such as: sedentariness, smoking and harmful alcohol consumption.

Concerning physical exercise, significant levels of sedentariness were found. The characteristics associated with low levels of exercising among the college students are influenced by some factors, including sex, age, employment situation, economic characteristics (monthly income, social class and whom the student lives with) and life habits (dieting or not). High levels of sedentariness are more frequent in students who have been at university longer when compared to sophomores, indicating a downward trend in physical exercise.

In the assessment of the biochemical data (triglycerides, HDL-cholesterol, fasting glucose), important triglyceride levels superior to expectations $(18.9 \%)$ and HDL-cholesterol below normal parameters $(64.5 \%)$ were found. In a study in the United States involving 189 students, ${ }^{20}$ it was identified that HDL-cholesterol was inferior to the suggested level in $20.1 \%$ and that the triglyceride levels were increased in $17.5 \%$ of the sample. The levels found here are higher and a source of concern for the college population with a view to the control of dyslipidemias.

The increased prevalence of BP in this public varies considerably. The result found here $(8.7 \%)$ was intermediary, lower than that observed in a study involving 667 college students from Lubango, Angola, which found $23.5 \%$ of students with above-normal pressure levels. ${ }^{21}$ On the other hand, it was higher than an analysis of 702 college students from Fortaleza-CE, which found $7.4 \%$ of students with increased blood pressure. ${ }^{18}$

Concerning the association between BP levels and sex, a higher prevalence of increased pressure levels was found among men than among women $(p<0.0001)$. Findings from different studies indicate a lower prevalence of $\mathrm{AH}$ in women when compared to men up to the age of 55 years and, after that age, a significant increase of the disease occurs among women. ${ }^{8,21}$

As to the students' lifestyle, smoking and drinking should be highlighted, as both were associated with altered BP levels. The exacerbated consumption of alcohol and cigarettes are factors that predispose to health problems and the development of diseases, which are interdependent elements that are hard to control. ${ }^{22}$ Nevertheless, alcohol consumption mostly happened in the medium-risk zone $(48.5 \%)$ and predominantly involved non-smokers (91.8\%).

Several authors highlight the need for interventions in the academic context. ${ }^{23-24}$ In an exploratory analysis at the University of Aveiro, Portugal, aiming to compare sophomores with veteran students, a higher percentage of smokers was demonstrated $(19.3 \%)$ among students exposed to the academic life than among sophomores $(0.0 \%)$, suggesting that a high education level does not seem to protect a healthier lifestyle. ${ }^{24}$

As regards drinking, $64.2 \%$ of the students consumed alcoholic beverages. Despite this high frequency, the majority who consumed alcohol was rated in the low and medium-risk zones. Lower rates can be observed in the literature, like in a study developed at Universidade Salgado de Oliveira, Goiânia Campus, involving 200 nursing students, which appointed that $53 \%$ of the students consumed alcohol, besides $36 \%$ of the students mentioned increased consumption after they had started college. ${ }^{25}$

In addition, a strong association was observed between central obesity and high pressure levels. Central obesity is an important risk factor for the development and progression of cardiovascular diseases, with clearly known harmful effects described by different authors, ${ }^{8}$ besides the fact that the fat distribution is another important risk factor for obesity-related diseases. ${ }^{23}$ Overweight with central fat deposits is a factor predisposing to high blood pressure. The prevalence of $\mathrm{AH}$ among obese people is higher when compared to non-obese individuals. ${ }^{21}$

The association between $\mathrm{WC}$ and $\mathrm{AH}$ was also analyzed in a similar study developed at Universidade Federal do Piauí, involving 605 students, when it was discovered that abdominal obesity was present in $2.4 \%$ of the students, independently of gender. A lower rate than that found in this study, with $5.8 \%$ of WC above normal standards. $^{8}$

\section{CONCLUSION}

Based on the analysis of the students' pressure levels, isolated cases above the ideal parameters were found, while participants with high BP simultaneously presented increased $\mathrm{WC}$, associated with smoking and drinking $(\mathrm{p}<0.05)$. These findings evidence that, even in a young popula- 
tion, the accumulation of fat in the organism and central obesity are important determinants in the increase of blood pressure levels. Concerning the socioeconomic data, an association was found with the variables: sex, age range and economic class $(p<0.05)$. Nevertheless, no statistically significant association was found with the biochemical data.

One of the limitations in this study was the absence of statistical analysis that may infer on the cause and effect between high blood pressure and triggering factors, due to the impossibility of these analyses because of the cross-sectional design. Another limitation was not having investigated the students' institutional characteristics, such as the year of entry, class group and daily hours spent at college and associations with BP levels.

As the incidence and prevalence of chronic conditions increase considerably as age advances, it is important to execute prevention actions, so that these diseases are detected early, and to develop other studies to assess the strategies used, as well as the impact on this public's lifestyle.

\section{REFERENCES}

1. Garofolo L, Ferreira SRG, Miranda Junior F. Study of risk factors associated with Peripheral Arteriopathy in Japanese-Brazilians from Bauru (SP). Arq Bras Cardiol. 2014; 102(2):143-50.

2. Ministério da Saúde (BR). Secretaria de Vigilância em Saúde. Departamento de Análise de Situação de Saúde. Plano de ações estratégicas para o enfrentamento das doenças crônicas não transmissíveis (DCNT) no Brasil 2011-2012 [online]. Brasília (DF): MS; 2011 [acesso 2015 mai 10]. Disponível: http://actbr.org.br/uploads / conteudo/918_cartilha_dcnt.pdf

3. Ministério da Saúde (BR). Secretaria de Vigilância em Saúde. Secretaria de Gestão Estratégica e Participativa. Vigitel Brasil 2010: vigilância de fatores de risco e proteção para doenças crônicas por inquérito telefônico [online]. Brasília (DF): MS; 2011 [acesso 2015 mai 10]. Disponível: http:/ / bvsms. saude.gov.br/bvs/publicacoes/vigitel_2010.pdf

4. Silva FM, Budó MLD, Silveira CL, Badke MR, Beuter M. Hipertensão: condição de não doença - o significado da cronicidade na perspectiva dos sujeitos. Texto Contexto Enferm [online]. 2013 [acesso 2015 mai 10]; 22(1):123-31. Disponível em: http:/ / www.scielo.br/ scielo.php?pid=S010407072013000100015\&script=sci_abstract\&tlng=pt

5. Gasparotto GS, Gasparotto LPR, Rossi LM, Moreira NB, Bontorin MS, Campos W. Association between moment of the undergraduate course and cardiovascular risk factors in university students. Rev Latino-Am Enfermagem. 2013; 21(3):687-94.
6. Lima ACS, Araújo MFM, Freitas RWJF, Zanetti ML, Almeida PC, Damasceno MMC. Risk factors for Type 2 Diabetes Mellitus in college students: association with sociodemographic variables. Rev Latino-Am Enfermagem. 2014; 22(3):484-90.

7. Correia BR, Cavalcante E, Santos E. A prevalência de fatores de risco para doenças cardiovasculares em estudantes universitários. Rev Bras Clin Med. 2010; (8):25-9.

8. Martins MCC, Ricarte IF, Rocha CHL. Maia RB, Silva VB, Veras AB, Souza Filho MD. Pressão arterial, excesso de peso e nível de atividade física em estudantes de universidade pública. Arq Bras Cardiol. 2010; 95(2):192-9.

9. Secretaria Nacional de Políticas sobre Drogas (BR). I Levantamento Nacional sobre o uso de álcool, tabaco e outras drogas entre universitários das 27 capitais brasileiras. Brasília (DF): Secretaria Nacional de Políticas sobre Drogas; 2010.

10. Shafey O, Dolwick S, Guindon GE, editors. Tobacco country profiles. Proccedings of the 12Th World Conference on Tabacco or Health. $2^{\text {nd }}$ ed. Helsinki (FI): World Health Organization, and International Union Against Cancer; 2003.

11. Méndez EB. Uma versão brasileira do AUDIT (Alcohol Use DisordersIdentification Test) [tese]. Pelotas (RS): Universidade Federal de Pelotas; 1999.

12. Figlie NB, Pillon SC, Dunn J, Laranjeira R. The frequency of smoking and problem drinking among general hospital inpatients in Brazil - using the AUDIT and Fagerström questionnaires. São Paulo Med J. 2000; 118(5):139-43.

13. Sociedade Brasileira de Cardiologia. IV Diretriz Brasileira Sobre Dislipidemias e Prevenção da Arterosclerose. Arq Bras Cardiol. 2007; 88(supl1):219.

14. Sociedade Brasileira de Cardiologia. Sociedade Brasileira de Hipertensão. Sociedade Brasileira de Nefrologia. VI Diretrizes Brasileira de Hipertensão. Arq Bras Cardiol. 2010; 95(1 Supl.1):1-51.

15. Instituto Brasileiro de Geografia e Estatística. Censo Demográfico 2010. Brasília (DF): IBGE [acesso 2014 Jul 15] Disponível em: http://www.censo2010. ibge.gov.br

16. Lira Neto JCG, Silva AP, Costa EPN, Silva ARV, Freitas RWJF. Analysis of overweight and obesity in university students. Rev Enferm UFPE [online]. 2012 [acesso 2015 mai 10]; 6(11):2770-6. Disponível em: http://www.revista.ufpe.br/revistaenfermagem/ index.php/revista/article/view/3193/pdf_1665

17. Silva LR, Silveira SS, Freitas RWJF, Sousa VEC, Barbosa ICFJ, Damasceno MMC. Risk fators for diabestes mellitus type 2 in nursing students. Rev Enferm UFPE [online]. 2011 [acesso 2015 mai 10]; 5(3):757-63. Disponível em: http://www.revista. ufpe.br/revistaenfermagem/index.php/revista/ article/viewArticle/1661 
18. Pereira DCR, Araújo MFM, Freitas RWJF, Teixeira CRS, Zanetti ML, Damasceno MMC. Neck circumference as a potential marker of metabolic syndrome among college students. Rev Latino-Am Enfermagem. 2014; 22(6):973-9.

19. Fontes ACD, Vianna RPT. Prevalência e fatores associados ao baixo nível de atividade física entre estudantes universitários de uma universidade pública da região Nordeste - Brasil. Rev Bras Epidemiol. 2009; 12(1): 20-9.

20. Fernandes J, Lofgren IE. Prevalence of metabolic syndrome and individual criteria in college students. J Am Coll Health. 2011; 59(4):313-21.

21. Simão $M$, Hayashida $M$, Santos $C B$, Cesarino EJ, Nogueira MS.. Hipertensão arterial entre universitários da cidade de Lubango, Angola. Rev Latino-am Enfermagem [online]. 2008 [acesso 2015 mai 10]; 16(4): Disponível em: http:/ / www.revistas. usp.br/rlae/article/viewFile/16988/18906
22. Mascena GV, Cavalcante MSB, Marcelino GB, Holanda SA, Brandt CT.Fatores de risco cardiovascular em estudantes da Faculdade de Ciências Médicas de Campina Grande. Medicina (Ribeirão Preto). 2012; 45(3):322-8.

23. Ramis TR, Mielke GI, Habeyche EC, Oliz MM, Azevedo MR, Hallal PC. Tabagismo e consumo de álcool em estudantes universitários: prevalência e fatores associados. Rev Bras Epidemiol. 2012; 15(2):376-85.

24. Brandão MP, Pimentel FL, Cardoso MF. Impact of academic exposure on health status of university students. Rev Saúde Pública. 2011; 45(1):49-58.

25. Barros CVL, Barros DAC, Bernardes MJC, Lima WV, Silva LCS. A influência do convívio universitário na adesão ao alcoolismo. Rev Eletr Itinerarius Reflectionis [online]. 2012 [acesso 2015 mai 10]; 2(13):1-12. Disponível em: http:/ / www.revistas. ufg.br/index.php/ritref/article/view/22312/13214 